\title{
$\mathrm{P}$ оль нейромедиаторов в развитии воспаления в коже больных атопическим дерматитом
}

\author{
О.Р. Катунина, В.В. Чикин, Л.Ф. Знаменская, Л.А. Иноятова
}

ФГБУ «Государственный научный центр дерматовенерологии и косметологии» Минздрава России 107076, Москва, ул. Короленко, д. 3, стр. 6

На формирование воспалительной реакции в коже, развитие зуда и на состояние нервных волокон могут влиять нейромедиаторы: нейропептиды и нейротрофины.

Цель. Оценить экспрессию нейропептидов и нейротросринов в коже больных атопическим дерматитом.

Материал и методы. В коже больных атопическим дерматитом методом иммуногистохимического анализа определяли

экспрессию нейропептидов субстанции Р и рецептора SP-R, пептида, связанного с геном кальцитонина (CGRP) и рецептора CGRP-R, нейротрофина - фактора роста нервов и рецептора TrkA, а также амфирегулина, способствующего росту нервных волокон, и семафорина-3А, прекращающего рост нервных волокон. Определяли также экспрессию белка PGP9.5, являющегося маркером нервных волокон.

Результаты. Обнаружено прорастание в эпидермис больных атопическим дерматитом нервных волокон, экспрессирующих субстанцию Р и CGRP. В эпидермисе выявлена экспрессия фрактора роста нервов и амсрирегулина, однако экспрессия семафорина-ЗА не была обнаружена.

Заключение. У больных атопическим дерматитом в эпидермис проникают нервные волокна, экспрессирующие нейропептиды субстанцию Р и CGRP, что может поддерживать у пациентов воспалительную реакцию и зуд. Способствовать росту нервных волокон и проникновению их в эпидермис может экспрессия фракторов роста (фрактора роста нервов и амсрирегулина) на сроне отсутствия экспрессии семасрорина-ЗА, подавляющего их рост.

Ключевые слова: атопический дерматит, иммуногистохимический анализ, эпидермис, нейропептиды, нейротрофины.

Контактная информация: chikin@cnikvi.ru. Вестник дерматологии и венерологии 2013; (5): 91_101.

\section{Role of neuromediators in the development of skin irritation in patients with atopic dermatitis}

\author{
O.R. Katunina, V.V. Chikin, L.F. Znamenskaya, L.A. Inoyatova
}

State Research Center of Dermatovenereology and Cosmetology Ministry of Healthcare of the Russian Federation Korolenko str., 3, bldg 6, Moscow, 107076, Russia

\footnotetext{
Neurotransmitters such as neuropeptides and neurotrophins can have an effect on the development of a skin inflammatory reaction and itching as well as condition of nerve fibers.

Goal. To assess the expression of neuropeptides and neurotrophins in the skin of patients with atopic dermatitis.

Materials and methods. Expression of neuropeptides of substance $P$ and SP-R receptor, calcitonin gene-related peptide (CGRP) and CGRP-R receptor, neurotrophin (nerve growth factor) and TrkA receptor as well as amphiregulin enhancing the growth of nerve fibers and semaphorin-3A terminating the growth of nerve fibers was determined in the skin of patients with atopic dermatitis based on the immunohistochemistry analysis method. Expression of protein PGP9.5 being a marker of nerve fibers was also determined.

Results. The authors discovered penetration of nerve fibers expressing substance P and CGRP into the epidermis in patients with atopic dermatitis. Expression of the nerve growth factor and amphiregulin was discovered in epidermis but no expression of semaphorin-3A was discovered. Conclusion. Nerve fibers expressing neuropeptides such as substance P and CGRP can penetrate into the epidermis in patients with atopic dermatitis, which can maintain the inflammatory reaction and itching in such patients.

Expression of the growth factors (nerve growth factor and amphiregulin) can contribute to the growth of nerve fibers and their penetration into epidermis against the background of the absence of any expression of semaphorin-3A inhibiting their growth.
}

Key words: atopic dermatitis, immunohistochemistry analysis, epidermis, neuropeptides, neurotrophins. 
Атопический дерматит - хроническое воспалительное заболевание кожи, начинающееся, как правило, в младенческом или детском возрасте. В патогенезе атопического дерматита ведущая роль отдается двум факторам - разрушению защитного липидного барьера и нарушениям иммунологической реактивности организма со сдвигом баланса между Th1- и Th2- лимфоцитами в сторону последних и повышением продукции соответствующих Th2-цитокинов [1-3]. Соответственно патогенетическая терапия больных атопическим дерматитом направлена на коррекцию защитного барьера кожи и подавление патологических Th2-клеточных реакций [4].

В то же время развитие и течение иммунных реакций в коже находится под влиянием периферической нервной системы $[5,6]$. Кожа считается наиболее обильно иннервированным органом человека [7]. Важное место в патогенезе хронических воспалительных дерматозов занимают чувствительные нервные С-волокна, окончания которых воспринимают действие пруритогенных стимулов и, следовательно, участвуют в формировании чувства зуда. От степени выраженности иннервации кожи нервными С-волокнами, которые представляют собой аксоны нейронов дорсального ядра спинного мозга, зависит интенсивность зуда у больных хроническими воспалительными дерматозами. Повышение плотности иннервации кожи, проникновение нервных волокон из дермы в эпидермис являются факторами, снижающими порог восприятия пруритогенных стимулов и способствующими развитию зуда.

Помимо своей основной функции - воспринимать стимулы внешней среды - чувствительные нервные волокна кожи способны влиять на развитие и течение воспалительной реакции в коже. Свободные нервные окончания, располагающиеся в коже, тесно примыкают к кератиноцитам и тучным клеткам, обеспечивая структурную основу для взаимодействий между этими клетками и нервными волокнами. При активации из нервных окончаний С-волокон выделяются нейропептиды, например CGRP и субстанция P. Нейропептиды, действуя через свои рецепторы, могут воздействовать на тучные клетки, лимфоциты, кератиноциты, стимулируя продукцию цитокинов и других биомолекул, способных модулировать течение воспаления [6].

В свою очередь, кератиноциты могут направлять рост аксонов нейронов дорсального ядра спинного мозга, что показано в экспериментах с культурами клеток [8]. Кератиноциты и фрибробласты дермы продуцируют как нейротрофные факторы, способствующие росту и ветвлению нервов, например фактор роста нервов $[9,10]$, так и хеморепелленты, прекращающие рост нервных волокон - семафорин-3А [11]. Поскольку эффекты влияния этих молекул на рост нервных волокон противоположны [12], их соотноше- ние позволяет установить точный контроль над иннервацией кожи.

Таким образом, нейропептиды и нейротрофины могут участвовать в формировании чувства зуда и развитии воспалительной реакции в коже, в связи с чем определение роли нейропептидов и нейротрофинов в патогенезе атопического дерматита может представить информацию об этих молекулах как о потенциальных терапевтических мишенях. В первую очередь это обусловливает необходимость определения локализации нейропептидов и нейротрофинов в структурах кожи, что возможно с помощью иммуногистохимического и иммунофлуоресцентного исследования.

Целью работы явилась оценка экспрессии нейропептидов и нейротрофинов в коже больных атопическим дерматитом.

\section{Материал и методы}

У 5 больных атопическим дерматитом в период обострения заболевания были получены биоптаты кожи из центральной части очагов поражения под местной анестезией (2\% раствор лидокаина). Биоптаты делили на две части. Одну часть биоптатов фриксировали в 10\% растворе забуференного фрормалина, подвергали стандартной гистологической проводке в автоматизированной вакуумной системе обработки тканей Leica ASP300 (Германия) путем обезвоживания в изопропиловом спирте. Далее кусочки ткани пропитывали парафином, заливали в парафиновые блоки, из которых на ротационном микротоме Leica RM2125RT (Германия) изготавливали срезы толщиной 5 мкм, растягивали на предметных стеклах с полилизиновым покрытием. Вторую часть биоптатов заливали в среду для замораживания Tissue-Tek (Sakura, Netherlands) и помещали в морозильную камеру при температуре $-30^{\circ} \mathrm{C}$. После замораживания на криостатном микротоме Slee (Германия) изготавливали срезы толщиной 5-6 мкм, растягивали их на предметных стеклах с полилизиновым покрытием, высушивали при комнатной температуре $25^{\circ} \mathrm{C}$ в течение 30 минут. После полного высыхания стекла со срезами помещали в фольгу и хранили в морозильной камере при температуре $-30{ }^{\circ} \mathrm{C}$.

Экспрессию маркера нервных волокон белка PGP9.5, амфирегулина, семафорина-3А, пептида, связанного с геном кальцитонина (CGRP) и его рецептора - CGRP-R, фактора роста нервов (NGF) и его рецептора TrkA, вещества $\mathrm{P}$ (SP) и его рецептора SP-R в структурах кожи больных атопическим дерматитом изучали иммуногистохимическим методом и методом иммунофрлюоресцентного окрашивания (непрямая РИФ).

При проведении иммуногистохимического исследования и иммунофлюоресцентного исследования за основу были взяты стандартные протоколы иммуно- 
гистохимической реакции и реакции непрямой иммунофлюоресценции (нРИФ) [13, 14].

В качестве вторичных биотинилированных антител был использован реагент Histofine Simple Stain MA PO (Multi) (Nichirei biosciences, Япония).

Полученные иммуногистохимические препараты изучали с помощью светового микроскопа Leica DM4000B (Германия), документировали цифровой камерой Leica DFC320 (Германия).

Препараты, полученные в результате проведения реакции непрямой иммунофрлюоресценции, анализировали и документировали на конфокальном лазерном сканирующем микроскопе Olympus IX81S1F-S (Германия) с использованием объективов × 60 и × 100.

В связи с тем, что различные комбинации нескольких обязательных этапов иммуногистохимического исследования (различная последовательность нанесения реактивов) могут критически влиять на качество иммуногистохимических препаратов, была проведена серия постановок иммуногистохимических реакций с использованием 3 протоколов, краткая последовательность выполнения которых представлена в таблице. В протоколах № 1 и 2 высокотемпературная демаскировка антигенных детерминант путем кипячения в цитратном буфере осуществлялась до нанесения пероксидазного блока, в протоколе № 3 - после нанесения пероксидазного блока. В протоколах № 2 и 3 перед инкубацией с первичными антителами на срезы наносился 5\% раствор БСА (бычий сывороточный альбумин).

При проведении серии экспериментов оптимальные результаты были получены в ходе проведения окраски согласно протоколу № 2, при использовании которого удалось добиться отсутствия неспецифического фонового окрашивания срезов. С целью достижения высокого качества иммуногистохимической окраски в протоколе № 2 был оптимизирован ряд стадий:

для достижения тщательной депарафинации срезов время пребывания стекол со срезами в термостате $\left(+56^{\circ}\right)$ было увеличено до 1 часа;

определено оптимальное рабочее разведение для всех концентрированных первичных антител 1:400. Также было отработано оптимальное время инкубации срезов с первичными антителами (60 в термостате при температуре $+37^{\circ}$ );

с целью демаскировки антигенных детерминант увеличено до 7' (трижды с 1-минутными перерывами) время кипячения срезов в цитратном буфере (pH 6,0);

пучшее качество иммуногистохимической окраски достигнуто за счет промывания срезов в растворе отмывающего фосфратного буфера, содержащего Tween20 (PBS+Tween20 pH 7,6 0 0,2), и увеличения кратности и времени промывания срезов - 3 раза по 7'; для предотвращения развития эндогенной пероксидазной активности оптимизировано функционирование иммуно-пероксидазной полимерной системы Histofain за счет нанесения на срезы 5\% раствора бычьего сывороточного альбумина, оптимальное время инкубации составило 60' при комнатной температуре.

Приводим оптимизированный протокол иммуногистохимической окраски парафиновых срезов, при котором были получены оптимальные результаты.

1. Приготовление буферных растворов для демаскировки антигенных детерминант (цитратный буфер $\mathrm{pH}-5,99-6,0)$ и для отмывания срезов в ходе реакции (ТРИС-бусрер рН - 7,54-7,58; фроссратный бусер (PBS) $\mathrm{pH}-7,4-7,8)$.

2. Предметные стекла со срезами помещаются в термостат $\left(+56^{\circ} \mathrm{C}\right)$ на 60 мин.

3. Для депарафинизации и дегидратации стекла со срезами из термостата последовательно помещаются в следующие жидкости:
ксилол - 5;
ксилол - 5;
ксилол - 5';
ксилол - 5';
- этиловый спирт 96\% - 5';
- этиловый спирт 96\% - 5'.

4. Для регидратации стекла со срезами помещают в дистиллированную воду на 10'.

5. Для демаскировки антигенных детерминант стекла со срезами помещают в контейнер с цитратным буфером (рH - 5,99-6,0), кипятят в СВЧ при мощности 900 Вт трижды по 7' с 1-минутными перерывами.

6. После остывания при комнатной температуре срезы промывают в дистиллированной воде в течение 5 '.

7. Для предотвращения эндогенной пероксидазной активности на срезы наносят пероксидазный блок (инкубация во влажной камере при комнатной температуре в течение 15').

8. Промывают срезы в PBS-буфере (или ТРИС-буфрере) трижды по 7'.

9. На срезы наносят протеиновый блок - 5\% раствор БСА, содержащий Tween20 (инкубация во влажной камере при комнатной температуре в течение 60').

10. Приготовление рабочих растворов первичных антител.

11. На срезы наносят первичные антитела (инкубация во влажной камере при температуре $37^{\circ} \mathrm{C}$ в течение 60').

12. Промывают срезы в PBS-буфере (или TPИСбуфере) трижды по 7'.

13. На срезы наносят вторичные биотинилированные антитела (инкубация во влажной камере при комнатной температуре в течение 30').

14. Промывают срезы в PBS-буфере (или ТРИСбуфере) трижды по 7'. 


\section{Таблица}

Протоколы проведения иммуногистохимического окрашивания парафиновых срезов биоптатов кожи больных атопическим дерматитом

\begin{tabular}{|c|c|c|c|}
\hline $\begin{array}{l}\text { № } \\
\text { п/п }\end{array}$ & Протокол № 1 & Протокол № 2 & Протокол № 3 \\
\hline 1. & Депарафинация срезов & $\begin{array}{c}\text { Поместить срезы в термостат } t^{\circ}+56^{\circ} \text { на } 30^{\prime} . \\
\text { Депарафинация срезов }\end{array}$ & $\begin{array}{c}\text { Поместить срезы в термостат } t^{\circ}+56^{\circ} \text { на } 30^{\prime} . \\
\text { Депарафинация срезов }\end{array}$ \\
\hline 2. & $\begin{array}{l}\text { Регидратация срезов в } \\
\text { дистиллированной воде }\end{array}$ & $\begin{array}{l}\text { Регидратация срезов } \\
\text { в дистиллированной воде }\end{array}$ & $\begin{array}{c}\text { Регидратация срезов в дистиллированной воде } \\
\text { затем промывание в проточной воде }\end{array}$ \\
\hline
\end{tabular}

3. Демаскировка антигенных детерминант в Демаскировка антигенных детерминант цитратном буфере $(\mathrm{pH} 5,9-6,0) \quad$ в цитратном буфере $(\mathrm{pH} 5,9-6,0)$

\begin{tabular}{cc} 
4. Пероксидазный блок & Пероксидазный блок \\
\hline $\begin{array}{c}\text { Промывание в буфере } \\
\text { (ТРИС, pH 7,54-7,58 или PBS, } \\
\text { pH 7,4-7,5) }\end{array}$ & Промывание в буфере (TPИС, pH 7,54-7,58 \\
& или PBS, pH 7,4-7,5)
\end{tabular}

6. Нанесение на срезы первичных антител, инкубация во влажной камере при комнатной температуре $\left(23-25^{\circ} \mathrm{C}\right)$ в течение 60

Инкубация срезов с БСА (бычий
сывороточный альбумин) для
предотвращения неспецифического
связывания антител

Нанесение на срезы первичных антител, инкубация во влажной камере при комнатной температуре $\left(23-25^{\circ} \mathrm{C}\right)$ в течение 60'
Пероксидазный блок

Промывание в буфере (ТРИС, pH 7,54-7,58 или PBS, pH 7,4-7,5)

Демаскировка антигенных детерминант в цитратном буфере $(\mathrm{pH} \mathrm{5,9-6,0)}$ 7. Промывание в буфере (ТРИС, pH
$7,54-7,58$ или PBS, pH 7,4-7,5)

8. Нанесение на срезы вторичных антител, Промывание в буфере (ТРИС, pH 7,54-7,58 инкубация во влажной камере при комнатной температуре $\left(23-25^{\circ} \mathrm{C}\right)$ или РBS, pH 7,4-7,5) в течение 30

Промывание в бусрере (ТРИС, pH 7,54-7,58 или PBS, $\mathrm{pH} 7,4-7,5)$

Инкубация срезов с БСА (бычий сывороточный альбумин) для предотвращения неспецифического связывания антител

Нанесение на срезы первичных антител, инкубация во влажной камере при комнатной температуре $\left(23-25^{\circ} \mathrm{C}\right)$ в течение $60^{\prime}$

\section{9. Промывание в буфере (ТРИС, $\mathrm{pH}$ 7,54—7,58 или PBS, pH 7,4—7,5)}

Нанесение на срезы вторичных антител, инкубация во влажной камере при комнатной температуре $\left(23-25^{\circ} \mathrm{C}\right)$ в течение 30

10. Визуализация реакции (DАВ-хромоген) Промывание в бусрере (ТРИС, pH 7,54-7,58 или PBS, pH 7,4-7,5)

Промывание в буфере (ТРИС, pH 7,54-7,58 или PBS, pH 7,4-7,5)

Нанесение на срезы вторичных антител, инкубация во влажной камере при комнатной температуре $\left(23-25^{\circ} \mathrm{C}\right)$ в течение $30^{\prime}$

\begin{tabular}{|c|c|c|c|}
\hline 11. & Докраска ядер гематоксилином & Визуализация реакции (DAB-хромоген) & $\begin{array}{c}\text { Промывание в буфере (ТРИС, pH 7,54-7,58 } \\
\text { или PBS, pH 7,4-7,5) }\end{array}$ \\
\hline 12. & $\begin{array}{c}\text { Заключение препаратов } \\
\text { под покровное стекло }\end{array}$ & Докраска ядер гематоксилином & Визуализация реакции (DAB-хромоген) \\
\hline 13. & & $\begin{array}{c}\text { Заключение препаратов } \\
\text { под покровное стекло }\end{array}$ & Докраска ядер гематоксилином \\
\hline 14. & & & Заключение препаратов под покровное стекло \\
\hline
\end{tabular}

15. Приготовление рабочего раствора DABсубстрата.

16. Проявление реакции (под контролем микроскопа) - на срезы нанести рабочий раствор DABсубстрата, промыть дистиллированной водой.

17. Докраска ядер гематоксилином - срезы подсушить, нанести гематоксилин Майера (инкубация во влажной камере при комнатной температуре в течение 5').

18. Промыть срезы дистиллированной водой дважды по 5'.
19. Для дегидратации стекла со срезами последовательно помещаются в следующие жидкости:

- этиловый спирт 96\% - 5';

चтиловый спирт 96\% - 5';

ксилол - 5';

ксилол - 5'.

20. Заключение в монтирующую среду под покровное стекло.

Основными проблемами при проведении реакции непрямой иммунофлюоресценции на замороженных срезах являлись потеря срезов при промывании в бу- 
ферном растворе, а также неспецифическое фроновое окрашивание. В процессе тестирования протокола нРИФ тщательно отрабатывалась каждая ступень протокола. С целью достижения высокого качества иммуносрлуоресцентной окраски срезов некоторые стадии протокола также были оптимизированы:

во избежание потери срезов и лучшей их адгезии к предметному стеклу проводили их размораживание в течение 30' при комнатной температуре, не вынимая из фольги;

- фриксацию срезов осуществляли, помещая их сначала в охлажденный раствор метанола в течение $10^{\prime}$ при температуре $\left(-20^{\circ} \mathrm{C}\right)$, затем в охлажденный раствор ацетона в течение 2' при температуре $\left(-20^{\circ} \mathrm{C}\right)$. Указанные растворы предварительно охлаждали в течение 60' при температуре $\left(-20^{\circ} \mathrm{C}\right)$;

- определено оптимальное рабочее разведение для всех концентрированных первичных антител 1:400. Также было отработано оптимальное время инкубации срезов с первичными антителами (60' в термостате при температуре $+37^{\circ}$ ).

было увеличено время промывания срезов до 10'; отмывание срезов проводилось на шейкере.

пля предотвращения эндогенной пероксидазной активности на срезы наносили 5\% раствор бычьего сывороточного альбумина, оптимальное время инкубации составило 60' при комнатной температуре.

Приводим протокол реакции непрямой иммуносрлюоресценции, при котором были получены оптимальные результаты.

1. Приготовление буферного раствора для отмывания срезов в ходе реакции (фосфратный буфер, содержащий Tween20 (PBS) pH - 7,4-7,8).

2. Размораживание предметных стекол со срезами при комнатной температуре в течение 30 мин.

3. Фиксация в охлажденном растворе метанола при температуре $\left(-20^{\circ} \mathrm{C}\right)$ в течение 10 мин., затем в охлажденном растворе ацетона при температуре $\left(-20^{\circ} \mathrm{C}\right)$ в течение 2 мин.

4. Промывают срезы в PBS-буфере трижды по 5'.

5. На срезы наносят протеиновый блок - 5\% раствор БСА, содержащий Tween20 (инкубация во влажной камере при комнатной температуре в течение 60').

6. На срезы наносят первичные антитела (инкубация во влажной камере при комнатной температуре В течение 60').

7. Промывают срезы в PBS-буфрере трижды по 10'.

8. На срезы наносят вторичные антитела, меченные флюоресцентным красителем (инкубация во влажной камере при комнатной температуре в течение 60').

9. Промывают срезы в PBS-буфере трижды по 10'.

10. Для докраски ядер наносят на срезы краситель DAPI.

11. Заключают препарат в реактив для заключения препаратов под покровное стекло.

\section{Результаты}

При анализе препаратов установлена высокая вариабельность экспрессии исследуемых нейропептидов.

Экспрессия белка PGP9.5 наблюдалась на нервных волоконцах, присутствующих рядом с потовыми железами (рис. 1, а) и в составе сосудисто-нервных пучков (рис. 1, б), между гладкомышечными пучками мышцы, поднимающей волос (рис. 2, а) и в нервных стволиках, присутствующих в дерме (рис. 2, б); тонкие PGP9.5 позитивные нервные волоконца обнаруживались в сосочковом слое дермы (рис. 3, а, в), а также прорастали между кератиноцитами (рис. 3, б, г).

Экспрессия белка амфирегулина (AR) выявлялась в эпидермисе в межклеточных промежутках (рис. 4, a, $\sigma, B, \Gamma)$.

Экспрессия белка CGRP (рис. 5, а) и его рецептора CGRP-R (рис. 5, б) наблюдалась на нервных волоконцах, прорастающих между кератиноцитами. Реакция с
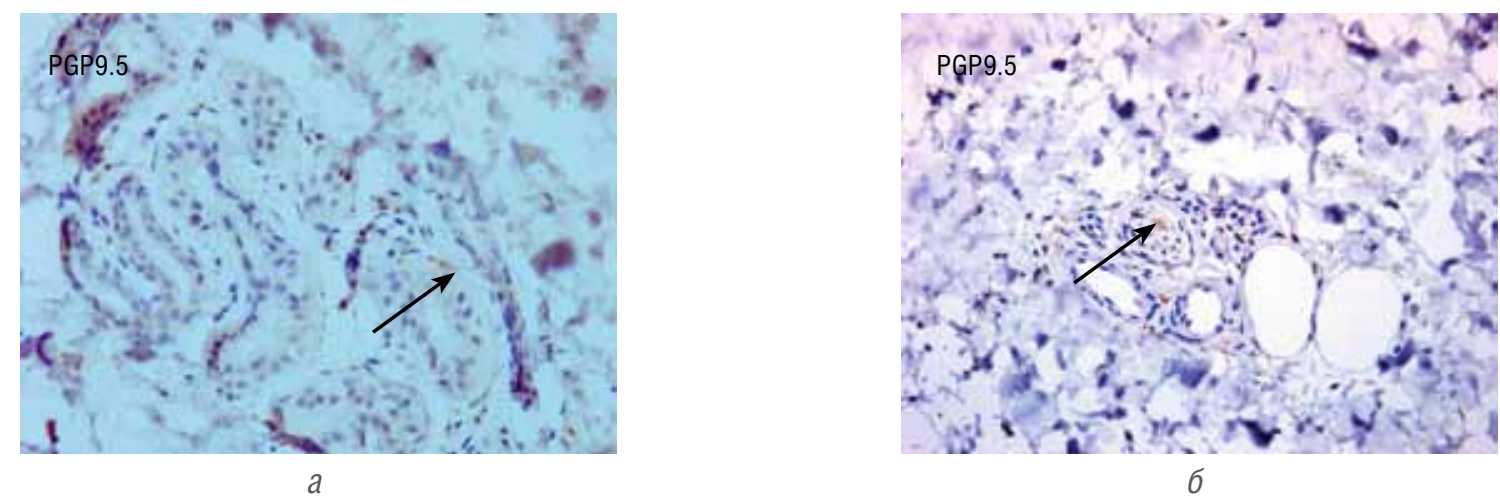

Pис. 1. Экспрессия PGP9.5 в коже больного атопическим дерматитом, иммуногистохимическая реакция; а - рядом с потовой железой (× 200); б — в составе сосудисто-нервного пучка $(\times 200)$ 


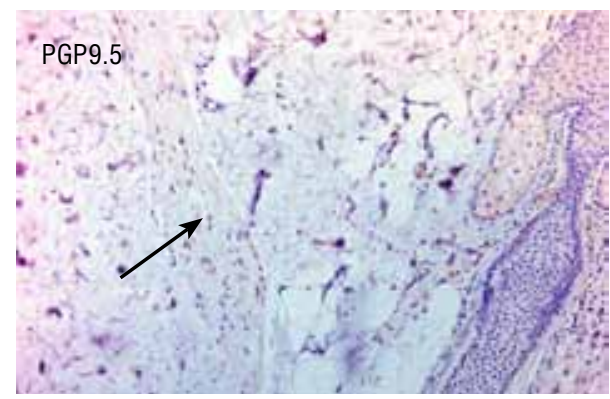

a

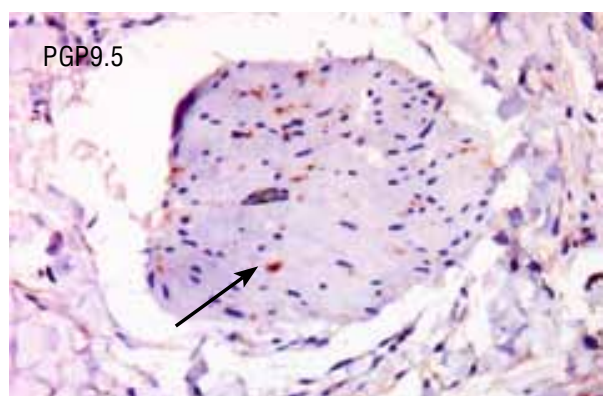

б

Pис. 2. Экспрессия PGP9.5 в коже больного атопическим дерматитом. Иммуногистохимическая реакция: а — между гладкомышечными пучками мышцы, поднимающей волос $(\times 200)$; б — в нервном стволике $(\times 400)$

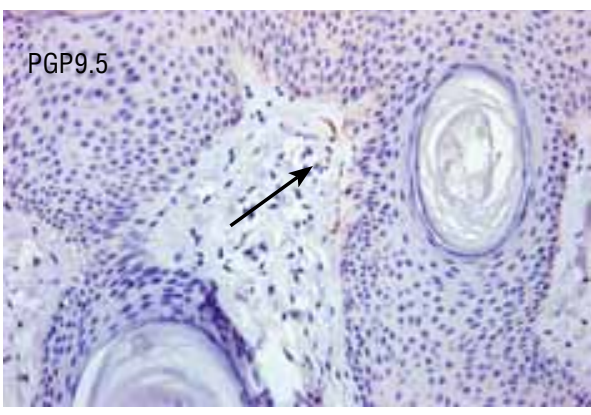

a

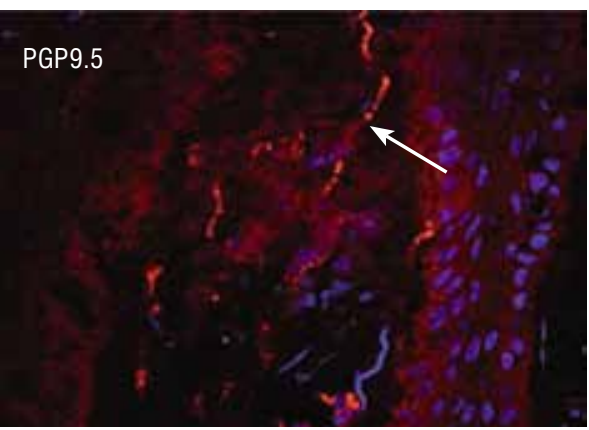

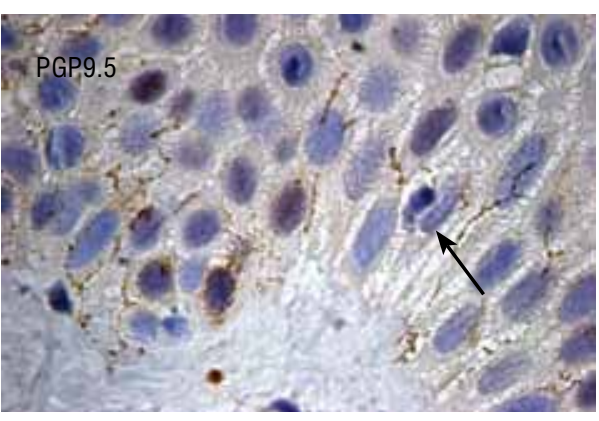

б

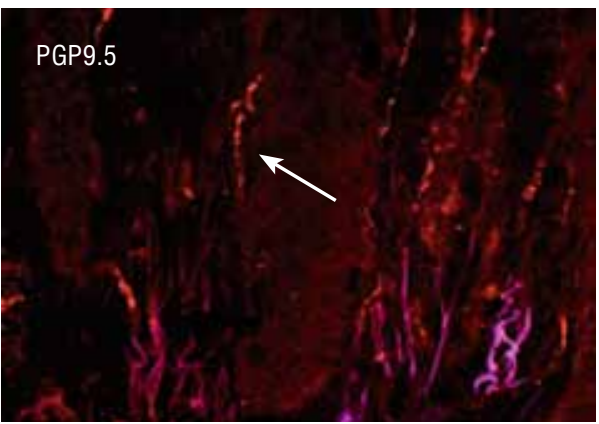

Рис 3. Экспрессия PGP9.5 в коже больного атопическим дерматитом. Иммуногистохимическая реакция: a - в сосочках дермы (× 200); б - между кератиноцитами $(\times 400) ;$ в - в сосочках дермы $(\times 600)$; $\Gamma$ - между кератиноцитами $(\times 600)$

моноклональными антителами к семафорину была отрицательной.

Экспрессия фактора роста нервов (NGF) наблюдалась в цитоплазме кератиноцитов (рис. 6, a, б).

Экспрессия вещества P (SP) наблюдалась на нервных волоконцах, прорастающих между кератиноцитами (рис. 7, а, б).
Экспрессия рецепторов к фактору роста нервов TrkA и к веществу P (SP-R) выявлялась в эпидермисе

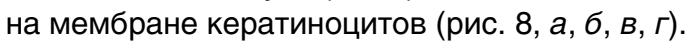

\section{Обсуждение}

Нейромедиаторы, к которым относятся нейропептиды и нейротрофины, были открыты как вещества, 

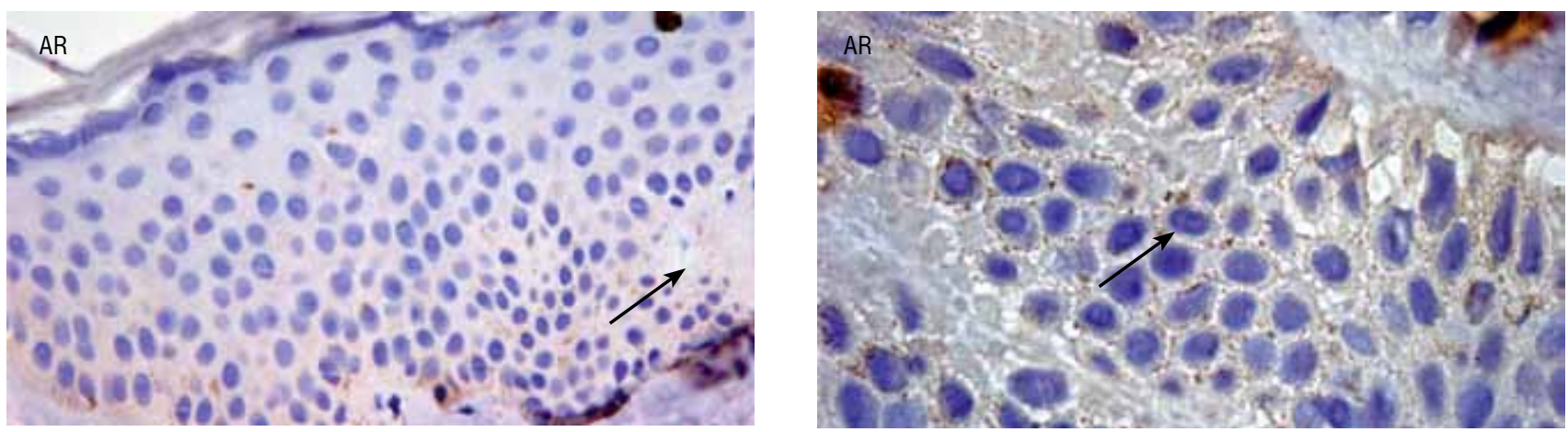

a

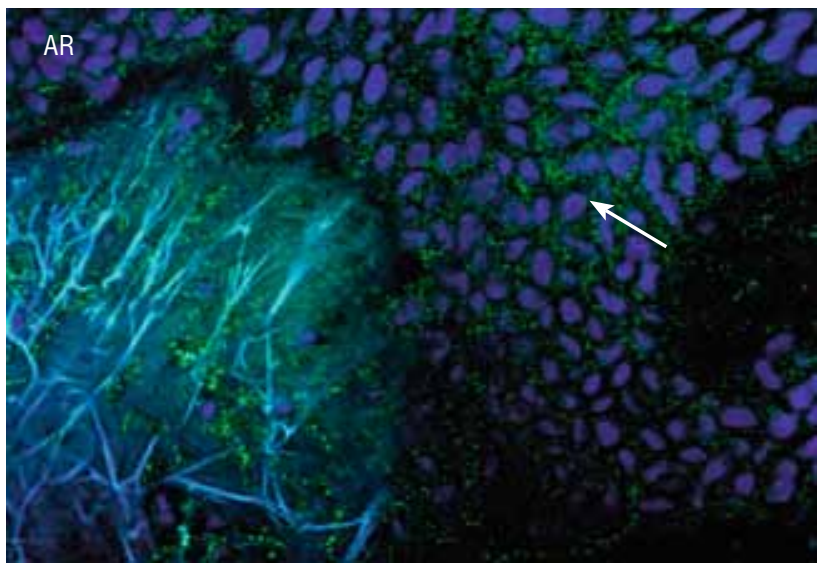

$B$

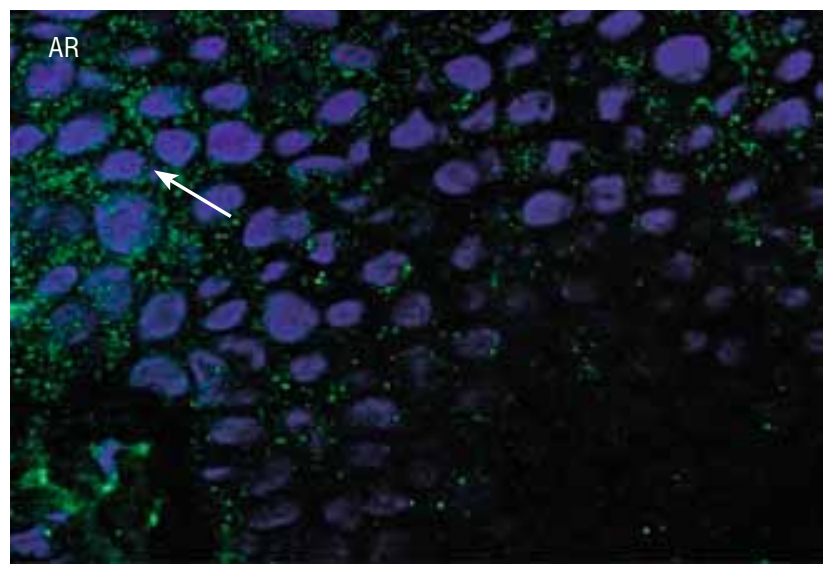

$\Gamma$

Рис. 4. Экспрессия амфрирегулина (AR) в коже больного атопическим дерматитом. Иммуногистохимическая реакция $(a-\times 200 ; \sigma-\times 400)$; реакция непрямой иммунофрлюоресценции $(в-\times 600 ;\ulcorner-\times 1000)$

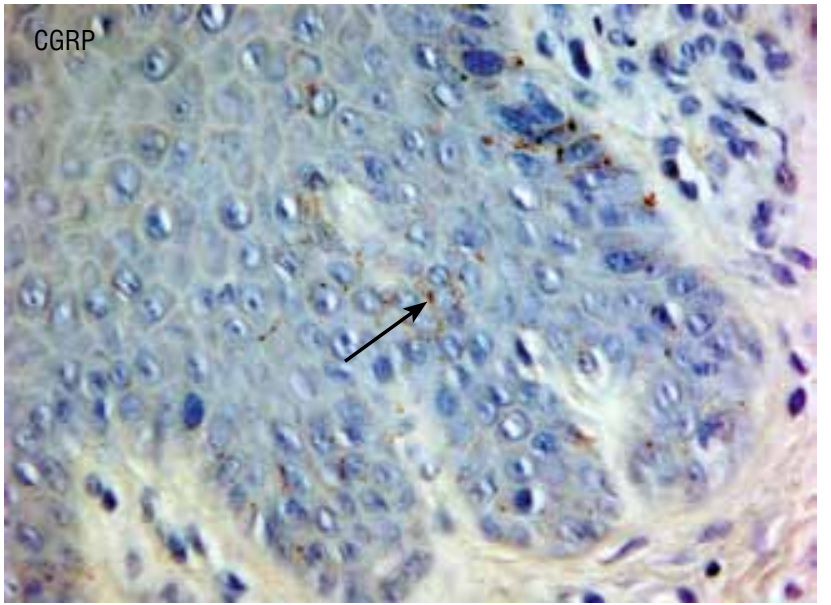

a

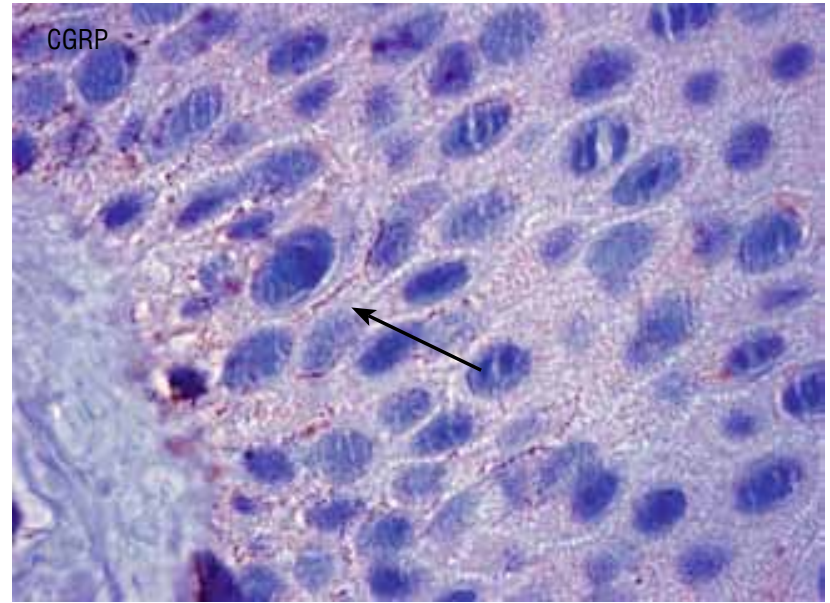

б

Рис. 5. Экспрессия CGRP $(a-\times 200)$ и CRRP-R $(б-\times 400)$ в коже больного атопическим дерматитом (иммуногистохимическая реакция) 


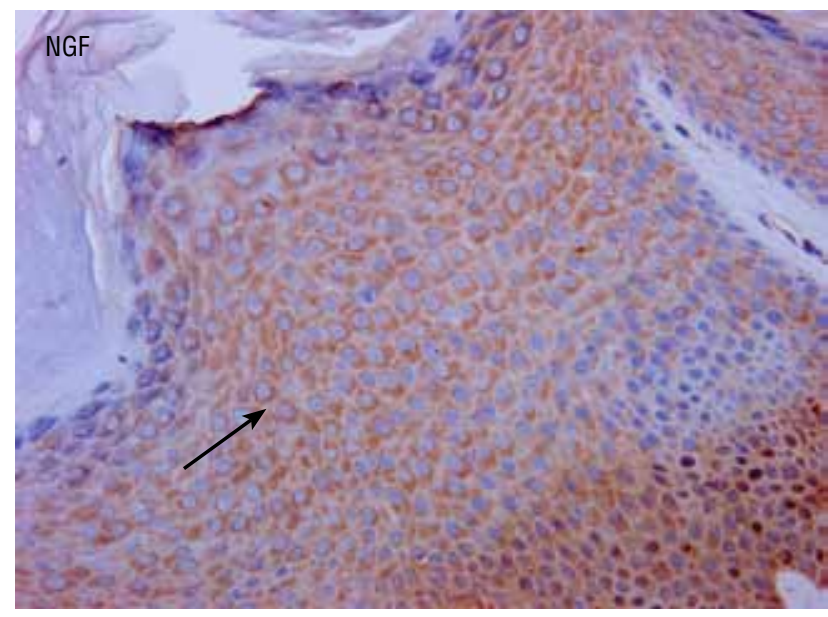

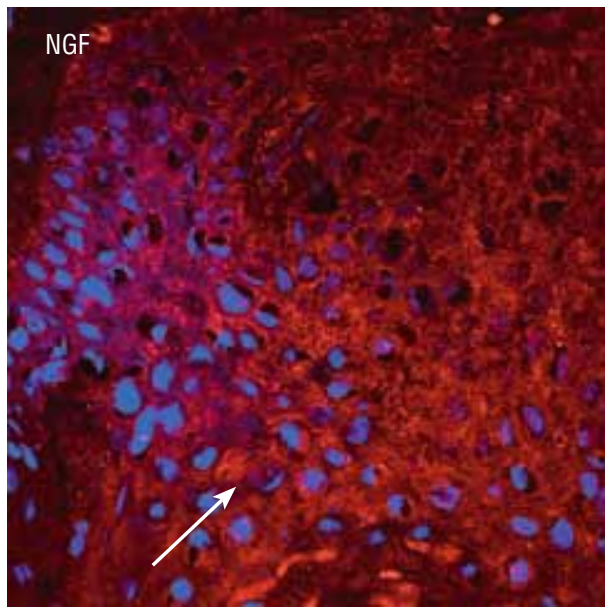

6

Рис. 6. Экспрессия фрактора роста нервов (NGF) в коже больного атопическим дерматитом: а - иммуногистохимическое исследование $(\times 200) ; \sigma$ - реакция непрямой иммунофлюоресценции $(\times 600)$

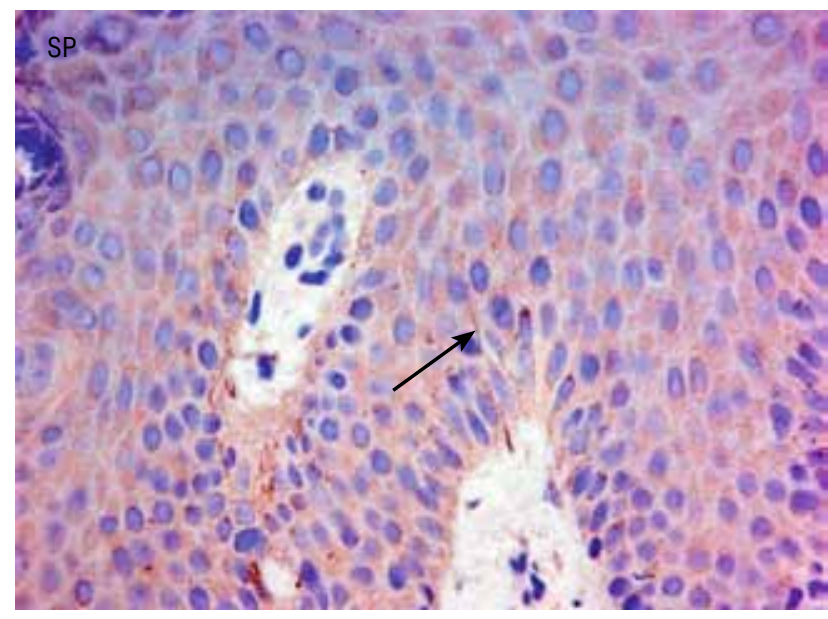

$a$

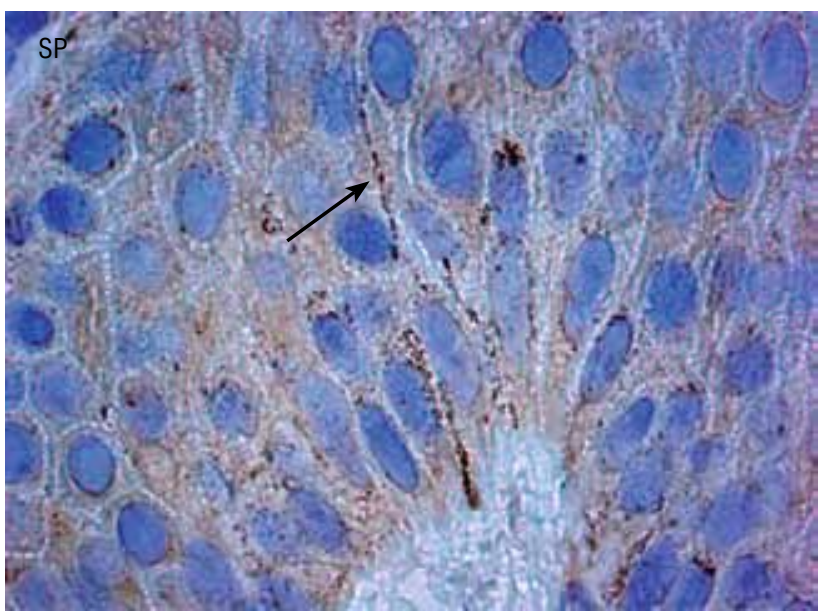

6

Рис. 7. Экспрессия субстанции P (SP) в коже больного атопическим дерматитом. Иммуногистохимическая реакция $(a-\times 200 ; \sigma-\times 1000)$

которые образуются в нервной системе и влияют на ее фрункции. Однако в последующем оказалось, что источники и мишени для этих веществ не ограничиваются нервной системой.

Со временем стало ясно, что продукция ФРН может происходить не только в нейронах, а сам нейротрофин обладает рядом биологических эфректов на клетки, которые не являются нейронами. В настоящем исследовании обнаружено присутствие ФРН в цитоплазме кератиноцитов. Это согласуется с результа- тами ранее проведенных исследований, показавших, что нормальные кератиноциты человека синтезируют и выделяют ФРН, который действует как фактор роста для этих клеток $[9,15,16]$. При этом ФРН в коже человека секретируется в больших количествах пролиферирующими кератиноцитами, тогда как в более диффреренцированных клетках его продукция прекращается [15].

Показано, что кератиноциты экспрессируют высокоаффринный рецептор TrkA, с которым связывается 


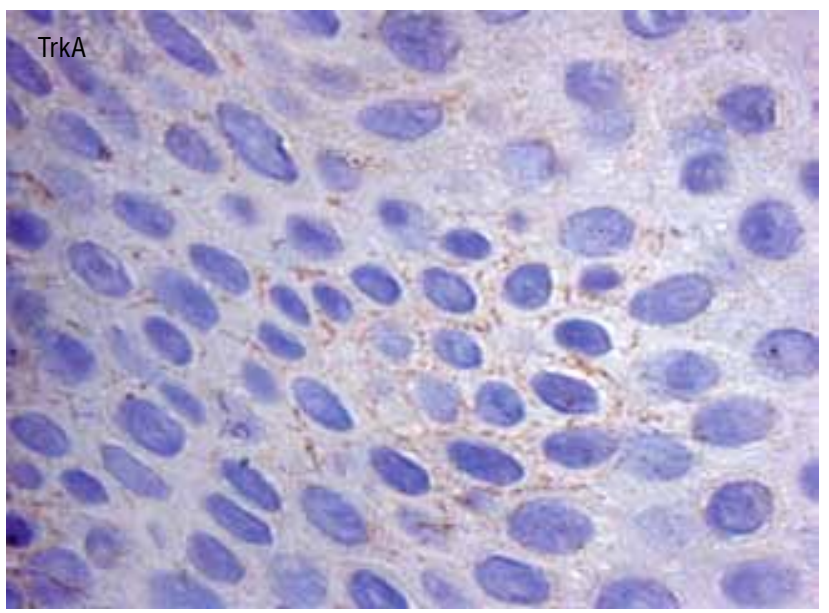

a

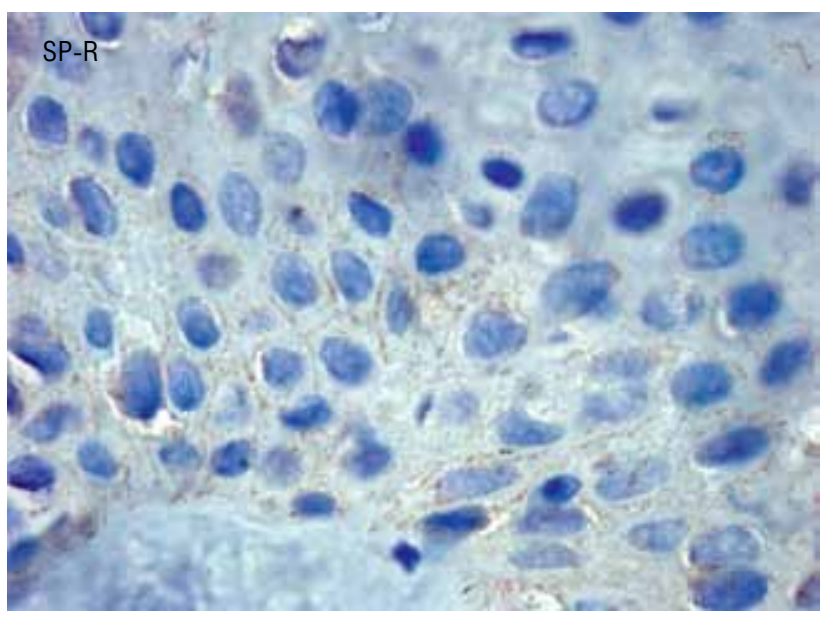

$B$

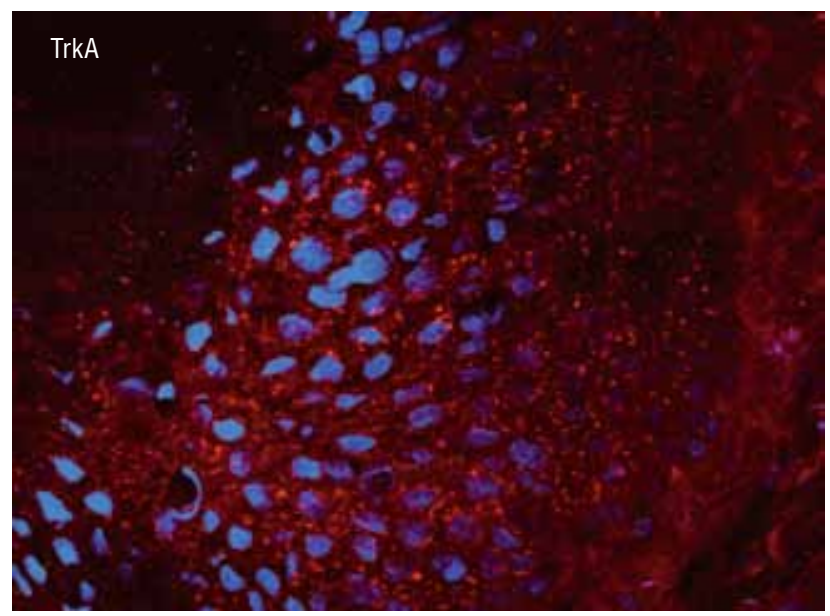

6

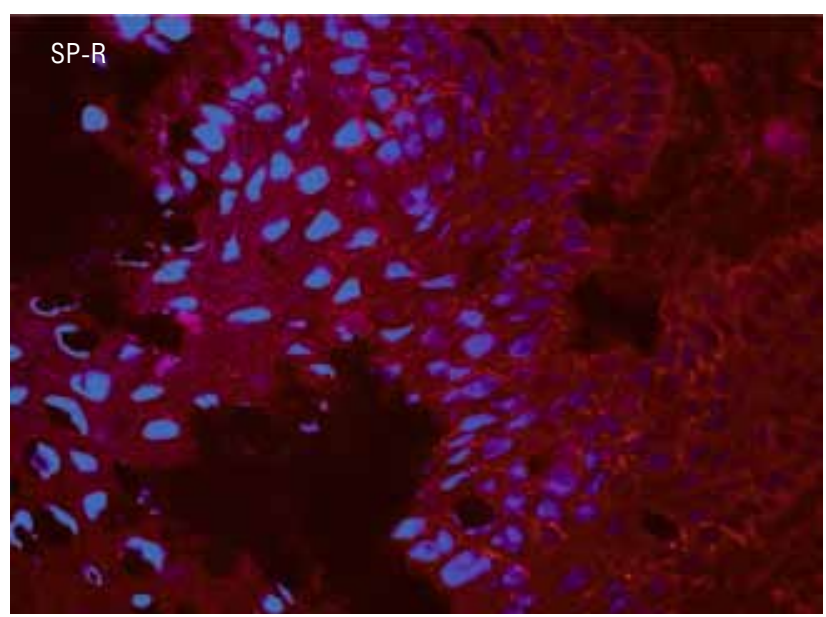

$\Gamma$

Pис. 8. Экспрессия рецептора к фрактору роста нервов (TrkA; $a$, б) и к субстанции P (SP-R; $B, \Gamma)$ в коже больного атопическим дерматитом: a, в - иммуногистохимическое исследование $(\times 400) ; \sigma, \Gamma$ - реакция непрямой иммунофрлюоресценции $(\times 600)$

ФРН [17]. Это подтверждается результатами настоящего исследования. С экспрессией TrkA кератиноцитами человека связывается способность ФРН индуцировать пролиферацию этих клеток [18].

Помимо ФРН в эпидермисе мышей была определена экспрессия амфирегулина [19]. Как и ФРН, амфирегулин способствует росту нервных волокон [20]. Тем самым он может повышать плотность иннервации кожи. В настоящем исследовании экспрессия амфирегулина была выявлена в межклеточных промежутках эпидермиса.

Нейротрофины, в частности фактор роста нервов, считаются первыми идентифицированными нейротрофными факторами, поддерживающими рост и развитие чувствительных нейронов, которые распространяют свои дендриты в кожу, тем самым играя роль в иннервации кожи [21]. Известно, что в здоровой коже большинство С-волокон заканчивается в области дермально-эпидермального соединения и лишь немногие из них проникают в эпидермис $[11,22]$. Прорастание нервных волокон в эпидермис между кератиноцитами у больных атопическим дерматитом, обнаруженное в настоящем исследовании, может быть следствием продукции ФРН и амфирегулина.

В то же время у обследованных пациентов не была выявлена экспрессия семафорина-ЗА. Ранее было показано, что это вещество может продуцироваться нормальными кератиноцитами эпидермиса [23, 24]. Семафорин-ЗА является антагонистом ФРН и препятствует разрастанию нервных волокон $[11,22]$. Тем самым отсутствие экспрессии семафорина-ЗА является 
дополнительным фактором, способствующим росту нервных волокон.

Чувствительные нервные С-волокна содержат нейропептиды, поэтому их разрастание сопряжено с повышением продукции нейропептидов, способных влиять на развитие и течение воспалительной реакции и способствовать развитию нейрогенного воспаления. Субстанция $\mathrm{P}$ - нейропептид, который выделяется из чувствительных нервных окончаний, вызывая развитие или распространение воспалительной реакции [25]. Субстанция Р является одним из ключевых фракторов в развитии нейрогенного воспаления в коже. Показано, что это вещество присутствует в дерме [26]. В настоящем исследовании у обследованных больных атопическим дерматитом присутствие субстанции $\mathrm{P}$ было выявлено на нервных волокнах, прорастающих в эпидермис между кератиноцитами, на мембранах которых определялась экспрессия рецепторов к субстанции Р. С этими данными согласуются результаты ранее проведенных исследований, выявившие, что культивируемые кератиноциты эпидермиса и фибробласты экспрессируют рецептор субстанции P NK-1R, а с помощью полимеразной цепной реакции в этих клетках была обнаружена MPHK белка NK-1R [27].

Показано, что при воздействии фактора роста нервов активированными Т-клетками и моноцитами мо- жет продуцироваться CGRP [28, 29]. Считается, что CGRP опосредует различные антивоспалительные и иммуносупрессивные эффекты и, следовательно, может играть роль в нейроиммунологических взаимодействиях [30]. Источником большей части циркулирующего CGRP являются чувствительные нервные окончания [31]. В настоящем исследовании экспрессия CGRP и его рецептора CGRP-R была выявлена на нервных волокнах, прорастающих между кератиноцитами.

\section{Заключение}

Получены данные об экспрессии нейропептидов и нейротрофинов, способствующих разрастанию нервных волокон, а также развитию воспаления и возникновению зуда, в эпидермисе больных атопическим дерматитом. Обнаружено, что у больных атопическим дерматитом в эпидермис проникают нервные волокна, экспрессирующие нейропептиды субстанцию P и CGRP, что может поддерживать у пациентов воспалительную реакцию и зуд. Способствовать росту нервных волокон и проникновению их в эпидермис может экспрессия факторов роста (фактора роста нервов и амфрирегулина) на фоне отсутствия экспрессии семафорина-3А, подавляющего их рост.

\section{Литература}

1. Elias P.M., Steinhoff M. "Outside-to-inside" (and now back to "outside") pathogenic mechanisms in atopic dermatitis. J Invest Dermatol 2008; 128 (5): $1067-1070$

2. Hanifin J.M. Evolving concepts of pathogenesis in atopic dermatitis and other eczemas. J Invest Dermatol 2009: 129: 320 -322.

3. Brandt E.B., Sivaprasad U. Th2 cytokines and atopic dermatitis. J Clin Cell Immunol 2011; 2 (3): pii: 110

4. Walling H.W., Swick B.L. Update on the management of chronic eczema: new approaches and emerging treatment options. Clin Cosmet Investig Dermatol 2010; 3: 99_117.

5. Raap U., Kapp A. Neuroimmunological findings in allergic skin diseases. Curr Opin Allergy Clin Immunol 2005; 5 (5): 419-424.

6. Steinhoff M., Stander S., Seeliger S. et al. Modern aspects of cutaneous neurogenic inflammation. Arch Dermatol 2003; 139: 1479-1488.

7. Roggenkamp D., Falkner S., Stäb F. et al. Atopic keratinocytes induce increased neurite outgrowth in a coculture model of porcine dorsal root ganglia neurons and human skin cells. J Invest Dermatol 2012; 132: 1892-1900.

8. Ulmann L., Rodeau J.L., Danoux L. et al. Trophic effects of keratinocytes on the axonal development of sensory neurons in a coculture model. Eur J Neurosci 2007; 26: 113-125.
9. Di Marco E., Marchisio P.C., Bondanza S. et al. Growth-regulated synthesis and secretion of biologically active nerve growth factor by human keratinocytes. J Biol Chem 1991; 266: 2171821722.

10. Botchkarev V.A., Yaar M., Peters E.M. et al. Neurotrophins in skin biology and pathology. J Invest Dermatol 2006; 126: 1719-1727.

11. Tominaga M., Ogawa H., Takamori K. Decreased production of semaphorin $3 \mathrm{~A}$ in the lesional skin of atopic dermatitis. Br J Dermatol 2008; 158: 842-844.

12. Dontchev V.D., Letourneau P.C. Nerve growth factor and semaphorin $3 \mathrm{~A}$ signaling pathways interact in regulating sensory neuronal growth cone motility. J Neurosci 2002; 22: 6659-6669.

13. Molekulyarnaya klinicheskaya diagnostika. Metody: Per. S angl./Pod red. S. Kherringtona, Dzh. Makgi. - M.: Mir, 1999. — 558 s. [Moлекулярная клиническая диагностика. Методы: Пер. с англ./Под ред. С. Херрингтона, Дж. Макги. М.: Мир, 1999. 558 c].

14. Rukovodstvo po immunogistokhimicheskoy diagnostike opukholey cheloveka. Izdanie 3-e, dopolnennoe i pererabotannoe./Pod. Red. S.V. Petrova, N.T. Raykhlina. - Kazan': "Titul", 2004. — 451s. [Руководство по иммуногистохимической диагностике опухолей человека. Издание 3-е, дополненное и переработанное/ Под. ред. С.В. Петрова, Н.Т. Райхлина. Казань: Титул, 2004. 451 с.]
15. Pincelli C., Fantini F., Giannetti A. Nerve growth factor and the skin. Int J Dermatol 1994; 33: 308-312.

16. Yaar M., Grossman K., Eller M., Gilchrest B.A. Evidence for nerve growth factor-mediated paracrine effects in human epidermis. J Cell Biol 1991; 115: 821—828.

17. Marconi A., Terracina M., Fila C. et al. Expression and function of neurotrophins and their receptors in cultured human keratinocytes. J Invest Dermatol 2003; 121: 1515-1521.

18. Di Marco E., Mathor M., Bondanza S. et al. Nerve growth factor binds to normal human keratinocytes through high and low affinity receptors and stimulates their growth by a novel autocrine loop. J Biol Chem 1993; 268: 22838-22846.

19. Tominaga M., Ozawa S., Ogawa H., Takamori K. A hypothetical mechanism of intraepidermal neurite formation in NC/Nga mice with atopic dermatitis. J Dermatol Sci 2007; 46: 199_207.

20. Nilsson A., Kanje M. Amphiregulin acts as an autocrine survival factor for adult sensory neurons. Neuroreport 2005; 16: 213-218.

21. Truzzi F., Marconi A., Pincelli C. Neurotrophins in healthy and disease skin. Dermato-Endocrinology 2011; 3 (1): 32-36.

22. Chang S.E., Han S.S., Jung H.J., Choi J.H. Neuropeptides and their receptors in psoriasis in relation to pruritus. Br J Dermatol 2007; 156 (6): 1272-1277. 
23. Kamo A., Tominaga M., Tengara S. et al. Inhibitory effects of UV-based therapy on dry skin-inducible nerve growth in acetone-treated mice. $J$ Dermatol Sci 2011; 62 (2): 91—97.

24. Fukamachi S., Bito T., Shiraishi N. et al. Modulation of semaphorin $3 \mathrm{~A}$ expression by calcium concentration and histamine in human keratinocytes nad fibroblasts. J Dermatol Sci 2011; 61 (2): 118-123.

25. Scholzen T., Armstrong C.A., Bunnett N.W. et al. Neuropeptides in the skin: interactions between the neuroendocrine and the skin immune systems. Exp Dermatol 1998; 7 (2—3): 81—96.
26. Inagaki N., Shiraishi N., Igeta K. et al. Depletion of substance $P$, a mechanism for inhibition of mouse scratching behavior by tacrolimus. Eur $\mathrm{J}$ Dermatol 2010; 626 (2-3): 283-289.

27. Liu J.Y., Hu J.H., Zhu Q.G. et al. Substance P receptor expression in human skin keratinocytes and fibroblasts. Br J Dermatol 2006; 155 (4): 657-662.

28. Xing L., Guo J., Wang X. Induction and expression of $\beta$-calcitonin gene-related peptide in rat $T$ lymphocytes and its significance. J. Immunol. 2000; 165: 4359—4366.
29. Bracci-Laudiero L., Aloe L., Caroleo M.C. et al. Endogenous NGF regulates CGRP expression in human monocytes and affects HLA-DR and CD86 expression and IL-10 production. Blood 2005; 106: 3507-3514.

30. Harzenetter M.D., Novotny A.R., Gais P. et al. Negative regulation of TLR response by the neuropeptide CGRP is mediated by the transcriptional repressor ICER. J Immunol 2007; 179: $607-615$.

31. Wimalawansa S.J. Amylin, calcitonin generelated peptide, calcitonin, and adrenomedullin: a peptide superfamily. Crit Rev Neurobiol 1997; 11: $167-239$.

об авторах:

О.Р. Катунина — д.м.н., доцент, заведующий патоморфологической лабораторией ФГБУ «ГНЦДК» Минздрава России, Москва

В.В. Чикин — К.м.н., старший научный сотрудник отдела дерматологии ФГБУ «ГНЦДК» Минздрава России, Москва

Л.Ф. Знаменская - к.М.Н., зав. отделом дерматологии ФГБУ «ГНЦДК» Минздрава России, Москва

Л.А. Иноятова — аспирант ФГБУ «ГНЦДК» Минздрава России, Москва 